\title{
MESTSKÝ PRIESTOR - STRATY A ZISKY PEŠIEHO ŽIVOTA
}

\section{URBAN SPACE - LOSSES AND VICTORIES OF PEDESTRIAN LIFE}

\author{
Ing. arch. Silvia Bašová, Ph.D.; Ing. arch. Lucia Štefancová, Ph.D. ${ }^{1}$
}

${ }^{1}$ STU Bratislava, Fakulta architektúry, Námestie Slobody 19, Bratislava 812 45, Slovensko

\begin{abstract}
ABSTRAKT
Živé, pulzujúce mesto je predpokladom a základom plnohodnotného urbánneho života. Typické prekážky ku komplexnému využitiu jeho verejných priestorov sú hlavne: podhodnotený priestor pre život peších, nízka atraktivita parteru ulíc a spoločenského využitia námestí, hluk dominantnej automobilovej dopravy, znečistenie, riziko nehôd, dehumanizácia a pod. Dvadsiate prvé storočie volá po verejných priestoroch príjemných pre peších, priatel'ským $\mathrm{k}$ ich priamym užívatel'om, priestoroch $\mathrm{s}$ čitatel'nou identitou a možnost'ou stretnutia. Vybrané príklady bratislavských verejných priestorov a verejných priestorov z Európy vyhodnocujú a porovnávajú straty, zisky a nádeje pretvorenia VP pre mestskost', identitu, kvalitu či zapamätatel’nost' pre účastníka deja - návštevníka. Tiež ponúkajú stratégiu „domino efektu“ pre mestské priestory príjemné pre peších, pre „city friendly spaces“.
\end{abstract}

Klíčová slova: verejný priestor, identita, faktory mestskosti, urbánny život, zapamätatel'nost', obraz mesta

\begin{abstract}
A vivid pulsating city is a premise and the essential substance of an active urban life. The typical obstacles for complex using of city public spaces are mainly: undervalued space for pedestrians, low attractiveness of street frontages and social use of squares, increased traffic, pollution, risk of accidents, dehumanization etc. Twenty-first century calls for public spaces pleasant for walking, users friendly areas with readable identity and the possibility of meetings. Selected examples of Bratislava public spaces and public spaces of other European cities evaluate and compare the losses, victories and hopes of possible transformations for the urbanity, identity, quality and memorability for the participants of the street action - the visitors. Selected cities also offer possible strategies of positive "domino effect" for urban spaces called "the city friendly pedestrian spaces". Recognition of the major role of pedestrians in urban life, necessity of balance in eco - urban structures and vision of appropriate social behavior afford the city a chance to emphasize the quality of public spaces.
\end{abstract}

Key words: public space, identity, urban factors, urban life, memorability, image of the city

\section{1 ÚVOD DO PROBLEMATIKY}

Živé, pulzujúce mesto je predpokladom a základom plnohodnotného urbánneho života. Mestské priestory by mali byt' oblúbené, príjemné, atraktívne. Mnohé reálne priestory sú však v skutočnosti hluché, prázdne, neútulné, pret’ažené dopravou a tým určené pre peších len na nevyhnutné „prejdenie“. Najvýznamnejšie námestia a ulice mesta tvoria hierarchickú kostru mestskej štruktúry a majú ponúkat' aj najvyššiu kvalitu urbanity. Už zo skúsenosti vývoja dejín mestských štruktúr sú overeným priestorom a istotou, ktorá akoby nepodliehala času a premenám. Hlavné námestie je stála urbánna priestorová scéna, ktorá svojou organizáciou a polohou výrazne napomáha orientácií v meste, dodáva mu atmosféru a identitu. Súčasné európske mestá vyzdvihli historické jadrá miest a ich nosné 
priestory, ale ostatné námestia ostávajú v procese premien a stále hl’adajú náplň, štrukturáciu, identitu a vitalitu. Typické prekážky $\mathrm{k}$ ich plnohodnotnému využitiu sú hlavne: podhodnotený priestor pre život peších, nízka atraktivita parteru ulíc a spoločenského využitia námestí, hluk dominantnej automobilovej dopravy, znečistenie, riziko nehôd, dehumanizácia. Dvadsiate prvé storočie volá po verejných priestoroch príjemných pre peších, priatel'ským $\mathrm{k}$ ich priamym užívatel'om, priestoroch s identitou a možnost'ou stretnutia. „Práve ako protiváha $k$ tol'kej nepriamej komunikácii a všadepritomnému súkromnému priestoru získava priame stretávanie l’udí, použivanie svojich zmyslov bezprostrednej interakcie takú atraktivitu." [4].

Funkčný model využívania verejného priestoru mesta sa počas histórie neustále mení. Mení sa aj vnímanie toho, čo všetko l'udia považujú za verejné priestory. Napriek odlišnostiam však môžeme definovat' tri funkcie, ktorým mesto slúžilo vždy. „Mesto vždy fungovalo ako miesto zhromažd'ovania, obchodu a dopravy." [4] Námestia a ulice boli miestami stretávania, kde občania mohli pestovat' kontakty medzi sebou navzájom i s návštevníkmi mesta, kde si vymieňali informácie o meste a spoločnosti a kde sa odohrávali dôležité udalosti: korunovácie, procesie, slávnosti, stretnutia občanov a verejné tresty. Mesto fungovalo tiež ako trhovisko, ponúkajúce tovary a služby a možnost' ich výmeny. Kvalita urbánneho života sa týka hlavne kvalitatívnej stránky života mesta ako celku, predovšetkým vo vzt'ahu k jeho obyvatel’om a návštevníkom.
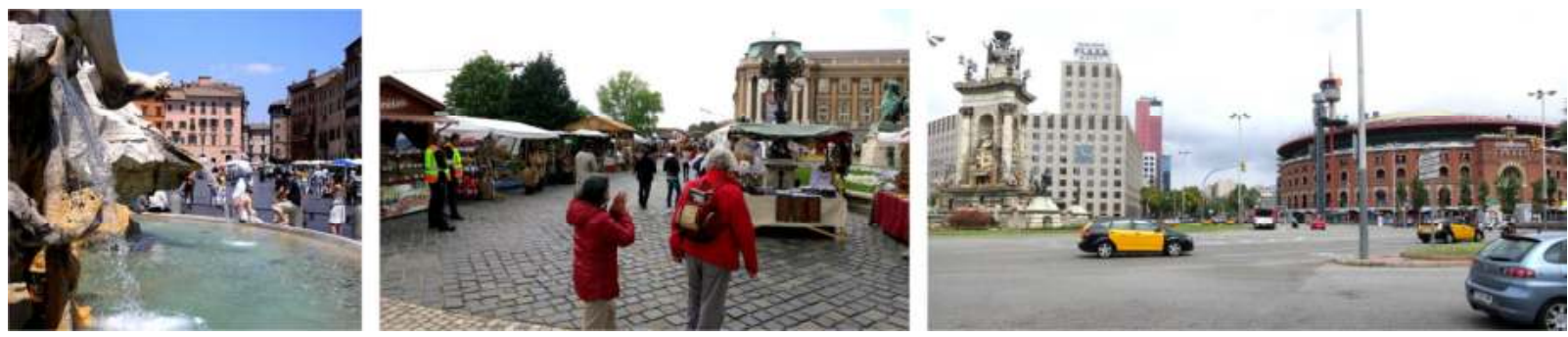

Obr.1: Základné funkcie VP (zl’ava: 1. zhromažd'ovanie / Rím, 2. obchod / Budapešt', 3. doprava / Barcelona). Foto: 1 - S. Bašová, 2,3 - L. Štefancová.

\section{MESTSKÉ PRIESTORY PRÍJEMNÉ PRE PEŠíCH}

\section{Straty pešieho života:}

- $\quad$ absencia dominantných peších trás

- $\quad$ enormný nárast automobilovej dopravy

- $\quad$ absencia atraktivity, kultúrnej sily a identity miest mesta

- $\quad$ slabé artikulovanie verejných priestorov

- nízka mestskost', funkčná prázdnota a nuda na námestiach

- úbytok vitálnych funkcií z centra

- $\quad$ privatizácia verejného priestoru
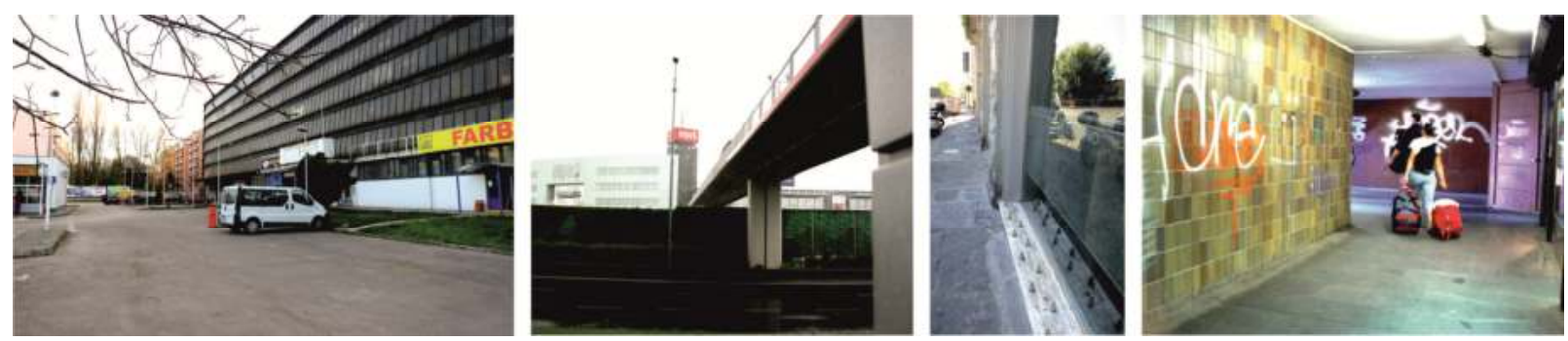

Obr.2: Príklady strát pešieho života (zl’ava: križovatka Tomášikova - Drieňová ulica, lávka do Auparku, Florencia, podchod na Trnavskom Mýte). Foto: L. Štefancová. 


\section{Zisky pešieho života:}

- $\quad$ kvalitný obraz mesta z horizontu chodca

- atraktívnost', variantnost' priestorov

- príjemná klíma a atmosféra miest

- $\quad$ zapamätatel'nost' miest

- $\quad$ pohyb, relax a pobyt vo verejnom priestore

- $\quad$ komunikatívnost' priestorov, interaktívnost' funkcií
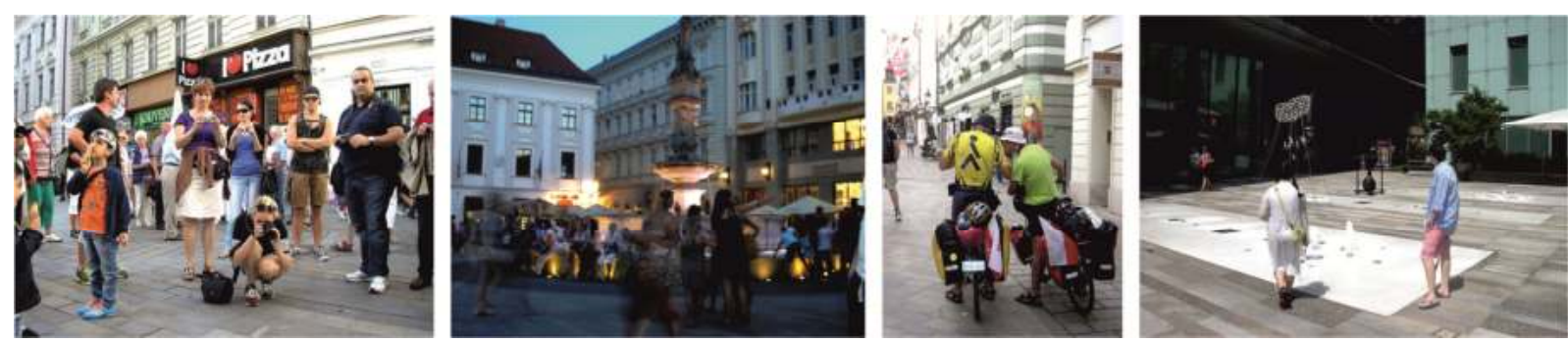

Obr. 3: Príklady ziskov pešieho života (zl’ava: 1-3 Hlavné námestie v Bratislave, 4 Riverpark ). Foto: S. Bašová.

\section{Nádeje pretvorenia mestských priestorov na mestotvorné miesta:}

- $\quad$ scenár pešieho mesta zdola i stratégia zhora

- $\quad$ interaktívne scenáre premeny mestských priestorov na víziu pešieho mesta

\subsection{Verejné priestory $v$ európskych mestách}

V súčasnom globalizovanom svete sa stierajú rozdiely medzi krajinami aj mestami. Všade sa nachádzajú série rovnakých firemných dizajnov a značiek, rovnaké autá, jednotný spôsob obliekania a pod. Zaniká identita miest aj ich t'ažiskových priestorov. Napriek tomu sa pomocou faktorov mestskosti dajú mestá rozanalyzovat' podrobnejšie a tým vyjadrit' ich zapamätatel'né špecifiká, súvisiace s identitou.

Vybrané príklady miest dokumentujú, v čom spočíva ich mestskost', straty a zisky pešieho života, identita, nádeje pretvorenia verejných priestorov na mestotvorné miesta či zapamätatel'nost' pre návštevníka. Faktory a princípy mestskosti sú univerzálne prvky, ktoré podporujú vitalitu a tým trávenie času vo verejných priestoroch. „Urbánny priestor by mal byt' čitatelný nielen ked' ideme po ulici, ale aj ked' spomíname. Priestorová a časová čitatel'nost' majú rovnaký význam." [8] Výber 5 miest súvisí s rôznorodostou a kontrastmi, ktoré sú pre verejné priestory dôležité.

\begin{tabular}{|c|c|c|c|}
\hline \multicolumn{4}{|c|}{ Mestský priestor - straty, zisky a nádeje pretvorenia pešieho života } \\
\hline $\begin{array}{l}\text { Európske mesto } \\
\text { (abecedne) }\end{array}$ & Straty pešieho života & Zisky pešieho života & $\begin{array}{l}\text { Nádeje } \\
\text { pretvorenia }\end{array}$ \\
\hline $\begin{array}{l}\text { Atény } \\
\text { if } \\
\text { ind }\end{array}$ & $\begin{array}{l}\text { chýbajúca jedinečná } \\
\text { identita VP a slabá } \\
\text { zapamätatel'nost' } \\
\text { - markízy zneprehl'adňujú } \\
\text { fasády a výšky budov } \\
\text { - zdevastované VP s s } \\
\text { vel'kým množstvom odpadu }\end{array}$ & $\begin{array}{l}\text { - univerzálna identita mesta } \\
\text { vo forme kaviarní a } \\
\text { balkónových terás } \\
\text { markízami do } \mathrm{s}=6 \mathrm{~m} \\
\text { - dominujú arkády } \mathrm{s} \\
\text { aktívnym parterom } \\
\text { - prevádzka automobilov len } \\
\text { jednosmerne }\end{array}$ & $\begin{array}{l}\text { uzavretia } \\
\text { niektorých } \\
\text { automobilových } \\
\text { komunikácií v } \\
\text { prospech } \\
\text { chodcov }\end{array}$ \\
\hline
\end{tabular}




\begin{tabular}{|c|c|c|c|}
\hline \multicolumn{4}{|c|}{ Mestský priestor - straty, zisky a nádeje pretvorenia pešieho života - pokračovanie } \\
\hline & $\begin{array}{l}\text { - monofunkčné a } \\
\text { rozvol'nené panelové obytné } \\
\text { zóny } \\
\text { q podpora automobilizmu } \\
\text { c čierne stavby a lobbing } \\
\text { developerských spoločností } \\
\text { množstvo prieluk a } \\
\text { nevyužívaných pozemkov } \\
\text { vo vnútornom meste }\end{array}$ & $\begin{array}{l}\text { - rôzne typy a mierky VP } \\
\text { - orientácia na princípe } \\
\text { zvyšovania hustoty mestských } \\
\text { blokov smerom k centru } \\
\text { - dominanty nadmestského } \\
\text { významu } \\
\text { - prírodné charakteristiky a } \\
\text { ich pešia dostupnost? }\end{array}$ & $\begin{array}{l}\text { - podpora } \\
\text { rekonštrukcie } \\
\text { objektov aj VP } \\
\text { absentujúcej } \\
\text { mestskosti }\end{array}$ \\
\hline & 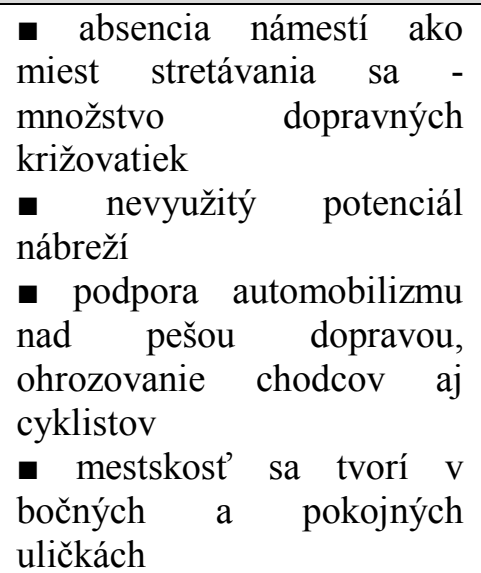 & $\begin{array}{l}\text { - zapamätatel'nými a } \\
\text { orientačnými faktormi sú } \\
\text { najmä } \\
\text { mestských akcentovanie } \\
\text { nárožiach blokov lokalizovanie } \\
\text { najstarších budapeštianskych } \\
\text { stavieb na nižšej nivelete ako } \\
\text { dobudované mesto } \\
\text { - dominujú fontány } \\
\text { - množstvo parkových úprav } \\
\text { s posedením }\end{array}$ & $\begin{array}{l}\text { - podpora } \\
\text { pešieho pohybu } \\
\text { - podpora } \\
\text { bezpečnosti } \\
\text { chodcov } \\
\text { pomocou } \\
\text { vegetácie } \\
\text { a mesto na } \\
\text { vode }\end{array}$ \\
\hline & $\begin{array}{l}\text { - neprípustné žiadne } \\
\text { moderné zásahy vo } \\
\text { vnútornom meste } \\
\text { - mesto s absenciou } \\
\text { výhradne peších zón } \\
\text { - všetky VP prístupné autám } \\
\text { a skútrom } \\
\text { - pešie trasy v šírke } 70 \mathrm{~cm}\end{array}$ & $\begin{array}{l}\text { - „kolíska kultúry" } \mathrm{s} \\
\text { absolútne zachovaným } \\
\text { mestským jadrom } \\
\text { - podvedomá orientácia v } \\
\text { meste na princípe rovnakých } \\
\text { profilov VP, z ktorých V } \\
\text { priehl'adoch sú viditel'né } \\
\text { dominantné architekt. objekty } \\
\text { alebo ich veže }\end{array}$ & $\begin{array}{l}\text { - vegetácia } \mathrm{v} \\
\text { kvetináčoch } \mathrm{s} \\
\text { tieniacou } \\
\text { funkciou } \\
\text { a vytváranie } \\
\text { posedení } \quad \text { a } \\
\text { pobyt. plôch }\end{array}$ \\
\hline & $\begin{array}{l}\text { - strohá architektúra } \\
\text { - málo orientačných bodov } \\
\text { - rozvojové osi s primárne } \\
\text { adminin. budovami } \\
\text { rovnakého charakteru } \\
\text { - živelnost' cyklo - dopravy }\end{array}$ & $\begin{array}{l}\text { moderné mesto s vysokou } \\
\text { kvalitou prevedenia VP } \\
\text { - rôznorodost' a atraktivita } \\
\text { - podpora zorných miest s } \\
\text { výhl'admi } \\
\text { - využívanie zmeny terénu }\end{array}$ & $\begin{array}{l}\text { - podpora } \\
\text { originality } \\
\text { budov na } \\
\text { jestvujúcich } \\
\text { kvalitných VP }\end{array}$ \\
\hline & $\begin{array}{l}\text { - turisticky pret’ažená } \\
\text { hlavná pešia tepna HJM } \\
\text { - chýbajúce identické uzly } \\
\text { mimo CMZ } \\
\text { - absencia relaxačných } \\
\text { príležitostí v jadre mesta } \\
\text { - kontrast areálu Wien-Mitte } \\
\text { s okolím a napojením na } \\
\text { jadro }\end{array}$ & $\begin{array}{lr}\text { - kompaktné } & \text { centrum } \\
\text { plnohodnotnej } & \text { kvalitnej } \\
\text { urbánnej štruktúry } & \\
\text { - zachovaná } & \text { objemná } \\
\text { substancia } & \text { historickej } \\
\text { štruktúry mesta } & \text { s aktuálnou } \\
\text { vitalitou } & \\
\text { - zapojenie parkov v CMZ do } \\
\text { línií pešieho života HJM }\end{array}$ & $\begin{array}{l}\text { - väčšie } \\
\text { využitie relaxu } \\
\text { nábrežia } \\
\text { Dunaja } \\
\text { - viac VP } \\
\text { s témou } \\
\text { kultúrnych } \\
\text { podujatí }\end{array}$ \\
\hline
\end{tabular}

Tab. 1: Verejné priestory príjemné pre peších - vybrané príklady európskych miest a porovnanie strát, ziskov a nádejí pretvorenia ich VP. Foto: L. Štefancová 


\subsection{Verejné priestory $v$ Bratislave}

„Rovina komplexného vyhodnotenia kvality verejných mestských priestorov môže byt' sústredená len na určité t'ažiskové kritéria a preto môže byt' len čiastočne objektivizovaná a vykazovaná." [1] Hlavné mesto sa prezentuje t’ažiskovou mestskou štruktúrou a sústredením sa na kultúrne a spoločenské dianie v HJM a v CMZ. Tak sa prirodzene počíta $\mathrm{v}$ najvýznamnejších verejných priestoroch viac $\mathrm{s}$ návštevníkmi domácej a turistickej klientely ako s účast'ou vlastných obyvatel'ov. Tento prístup „turistickej arény“ je však dost' jednostranný. Komplexnost' kvalitných verejných priestorov musí integrovat' svojich obyvatel'ov i návštevníkov v spoločnej priestorovej scéne a variantnej osnove dynamických i statických funkcií. Chybný dôraz na výraznú atraktivitu pre turistov redukuje príjemné bývanie $\mathrm{v}$ centre, čím znižuje jeho prirodzenú schopnost' byt' súčast'ou kvalitnej urbanity tých najvýznamnejších štruktúr mesta. Centrum Bratislavy má pred sebou vol’bu: pretvárat' verejné priestory s akceptáciou domáceho obyvatel'stva, s podnetmi rozvoja miešaných funkcií, s dôrazom na potreby detí a mladých, alebo stagnovat' $\mathrm{v}$ dôraze na exkluzívnost' a turistický ruch. Len vhodná previazanost' atraktívnych funkcií s bázickou funkciou bývania má šancu odolat' komerčným pohl'adom na downtown.

Dnešní obyvatelia miest vnímajú verejné priestory Bratislavy nie z hl'adiska toho, čo je vo vlastníctve štátu a čo je v súkromných rukách. Ako verejné vnímajú všetky priestory, kam môžu vstúpit' bez ohl’adu na dížku trvania počas dňa. Vitalita námestí a nábrežia, ulíc, pasáží a nádvorí je v sústredená do obnoveného historického jadra mesta a ako komerčným magnetom je verejnost' vt’ahovaná do nákupných centier. K návštevnosti nákupných centier prispieva aj „,monofunkčnost', nedostatok zariadeni občianskej vybavenosti a pasivita parteru obytných zón, v ktorých nedošlo $k$ realizácii t’ažiskových a mestotvorných funkcii a foriem." [3]

V roku 2012 prebehol štatistický prieskum, ktorý bol zameraný na zistenie vzt’ahu domácich obyvatel'ov a návštevníkov $\mathrm{k}$ mestu a $\mathrm{k}$ verejným priestorom. Ďalej bolo monitorované zistenie názorov na developerské projekty a nákupné centrá, zistenie pozitívnych zážitkov, ktoré prináša pobyt vo verejných priestoroch mesta a pod. Z prieskumu vyplynulo, že l'udia vo verejných priestoroch Bratislavy oceňujú kontrasty historických a moderných objektov, fontány, aleje a atrakcie. V spomienkach l’udí na iné mestá dominujú námestia, atmosféra a posedenie v kaviarňach. V tab.1 je popísaných 6 záverov, ktoré Bratislavčania opísali v súvislosti s rozvojom verejných priestorov.

\begin{tabular}{|c|c|c|}
\hline \multicolumn{3}{|c|}{ Závery zo štatistického prieskumu* o verejných priestoroch v Bratislave } \\
\hline & Vyhodnotenie: & $\begin{array}{l}\text { Vybrané príklady } \\
\text { respondentov: }\end{array}$ \\
\hline 1. & $\begin{array}{l}\text { Najdôležitejšie formy verejného priestoru sú rovnocenne námestia } \\
\text { a parky. }\end{array}$ & $\begin{array}{l}\text { - Hviezdoslavovo nám. } \\
\text { - Medická záhrada }\end{array}$ \\
\hline 2. & $\begin{array}{l}\text { Drobné elementy VP s vysokým vplyvom na zapamätatel'nost' sú } \\
\text { fontány a alejová vegetácia. }\end{array}$ & $\begin{array}{l}\text { - fontána na Nám. } \\
\text { Slobody, Dulovom nám. }\end{array}$ \\
\hline 3. & $\begin{array}{l}\text { Obyvatelia opisujú ako kladnú vlastnost’ Bratislavy najmä: } \\
\text { - výhodnú polohu, } \\
\text { - známu dominantu, } \\
\text { - pešiu dostupnost', ktorá umožňuje prejst' mesto a mat' zážitky } \\
\text { - automobilovú dostupnost', ktorá zabezpečí rýchly presun } \\
\text { mestom. }\end{array}$ & $\begin{array}{l}\text { - príroda v okolí a } \\
\text { lesoparky } \\
\text { - Bratislavský hrad, } \\
\text { Devín, Kamzík, Most } \\
\text { SNP, Dunaj } \\
\text { - pešia dostup. do } 1 \mathrm{~h} \\
\text { - automobilová } \\
\text { dostupnost' do } 20 \mathrm{~min}\end{array}$ \\
\hline
\end{tabular}




\section{Závery zo štatistického prieskumu* o VP v Bratislave - pokračovanie}

\begin{tabular}{|c|c|c|}
\hline 4. & 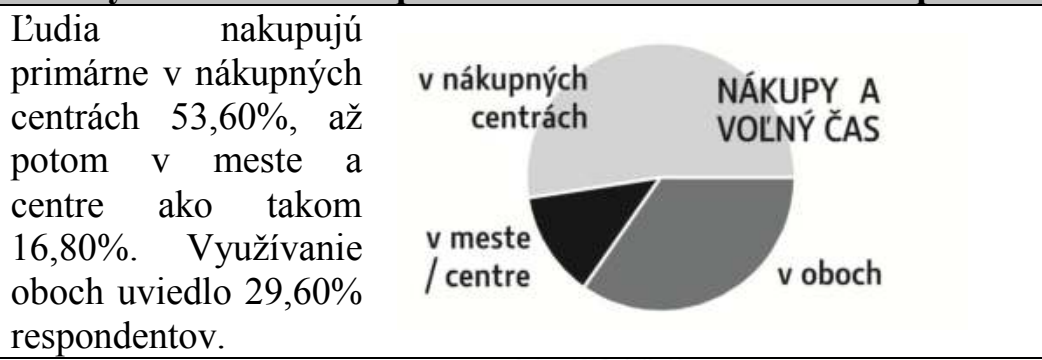 & $\begin{array}{l}\text { najvyhl'adávanejšie NC: } \\
\text { - Aupark, } \\
\text { - Eurovea } \\
\text { - Centrál }\end{array}$ \\
\hline 5. & 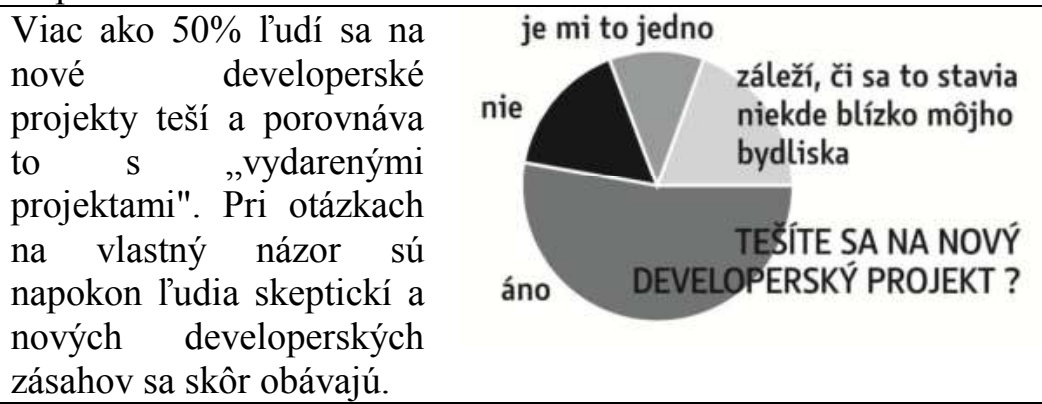 & $\begin{array}{l}\text { polarita názorov: } \\
\text { + Eurovea } \\
\text { - Aupark } \\
\text { - Riverpark } \\
\text { - rozostavané projekty } \\
\text { (OD Ružinov, Twin } \\
\text { City) }\end{array}$ \\
\hline 6. & $\begin{array}{l}\text { Základom úspešnosti pri výstavbe nového komplexu, zóny, alebo } \\
\text { budov je: } \\
\text { 1. vytvorenie dostatočne vel'kého verejného priestoru, ktorý bude } \\
\text { obsahovat' vel'a trávnatých prístupných plôch na oddych } \\
\text { (architektonicko-krajinárske návrhy priestorov, kríky a iné formy } \\
\text { nie sú nutné) } \\
\text { 2. zachovanie a sprístupnenie min. } 1 \text { historickej stavby, ktorá je } \\
\text { súčastou miesta } \\
\text { 3. vytvorenie komplexu, ktorý bude rôznorodý, t.j. využíva rôzne } \\
\text { výšky, materiály, kontrasty, rôzne typy mobiliáru, vel'a vstupov a } \\
\text { pod. } \\
\text { 4. umožnenie dostatočného parkovacieho potenciálu a toaliet } \\
\text { zadarmo }\end{array}$ & $\begin{array}{l}\text { Eurovea a Centrál ako } \\
\text { pozitívne developerské } \\
\text { investície }\end{array}$ \\
\hline \multicolumn{3}{|c|}{$\begin{array}{l}\text { *štatistický prieskum [9]: } \\
\text { - autorka a spracovatel'ka L. Štefancová }\end{array}$} \\
\hline
\end{tabular}

Tab. 2: - Závery zo štatistického prieskumu o verejných priestoroch v Bratislave.

\subsection{Vyhodnotenie verejných priestorov vybraných európskych miest}

Vybrané príklady bratislavských verejných priestorov a verejných priestorov z Európy komparovali straty, zisky a nádeje pretvorenia verejných priestorov pre mestskost', identitu, kvalitu či zapamätatel'nost' pre účastníka deja - návštevníka. Tiež ponúkli stratégiu „domino efektu“ pre mestské priestory príjemné pre peších - „city friendly pedestrian spaces“. Domino efekt ako reakcia spustená malou zmenou, ktorá bezprostredne ovplyvní najprv len svoje najbližšie okolie, ale postupne sa rovnakým spôsobom šíri aj do vzdialenejších oblastí. Domino efekt spôsobuje, že aj malá lokálna zmena môže mat' globálny následok.

Sústava malých zmien spustená podnetom pre riešenie otázky dominancie peších $\mathrm{v}$ meste, sprevádzaná profesionalitou a za účasti verejnosti bola vel'mi úspešne spustená napr. v Dánsku, pod vedením Jan Gehla, neskôr teamu Gehl Architects. Začiatky princípu siahajú k myšlienke dôrazu na 
vzt’ah medzi urbánnym prostredím a kvalitou života jeho obyvatel'ov. Mestá pre l’udí, ako silná idea, je dodnes t'ažiskovou témou projektov tohto zoskupenia, dnes už so zastúpením v 50-tich krajinách sveta a s prínosom pre tvorbu verejného priestoru vo viac ako 250 mestách sveta.

Peší pohyb a miesta zastavenia peších - dva póly jednej skutočnosti, dva póly akcentu na peší život v meste vychádzajú z dôležitosti vnímania mesta z horizontu chodca. Význam orientácie podl’a dominánt a akcentov je potrebný pre dynamiku pešej chôdze, približovanie sa k ciel’u. Námestia, ako ciel’ové destinácie pohybu, sa potom stávajú scénou pre pobyt a zotrvanie. Pri vnímaní celku námestia sa jeho účastníci nakoniec zamerajú na určité miesto, alebo sústavu miest, ktoré ich zaujmú a pritiahnu. Význam miesta, tu tvorí jednak celé námestie, ale aj jeho čast', atraktívne miesto, ktoré dáva jedinečnú možnost' zažit' konkrétny dej na námestí, alebo oddych v jeho pozíciách sedení. Takto námestie evokuje okrem svojej stálej funkčnej ponuky možnost' prezentácie rozmanitých vol’ných aktivít (umelecké vystúpenia na pódiách, živé sochy, animácie a pod.). Následne vidno oblubu a preferenciu určitých námestí v hodnotení ich návštevníkmi. Najviac preferované priestory nakoniec reprezentujú najvyššiu kvalitu mestských centier a tie signalizujú kvalitu miest.

Podl'a prieskumov kvality života v mestách s vyhodnotením 223 top miest z celého sveta z roku 2013 nadnárodnej spoločnosti WCRR [7], je zaujímavost’ou dominancia najvy̌šsej kvality u európskych vel'kých a stredných miest. Top mestom sa stala Viedeň. Prvenstvo mesta Viedne v danom hodnotení, je prekvapujúce. Potvrdzuje skvelú vyváženost' klasického a vitálneho konceptu mesta, spojeného s perspektívami kultúrno - sociálneho rozvoja, v opore o vysoko rozvinutú urbánnu a technickú infraštruktúru. Ďalej nasledujú v rebríčku kvality mestá: Zürich, Auckland, Mníchov, Vancouver, Düsseldorf, Frankfurt, Ženeva atd'. Tento prieskum upozorňuje na trendy, ktoré môžu pomôct' urbanistom a architektom $\mathrm{k}$ úspešnosti ich konceptov. Pre mesto sú tieto prieskumy výhodnou orientáciou v rozhodovaní pre d’alší rozvoj v danom mestskom priestore, a to nielen v zmysle urbánnej kvality, ale aj v zmysle návratnosti vložených investičných prostriedkov.
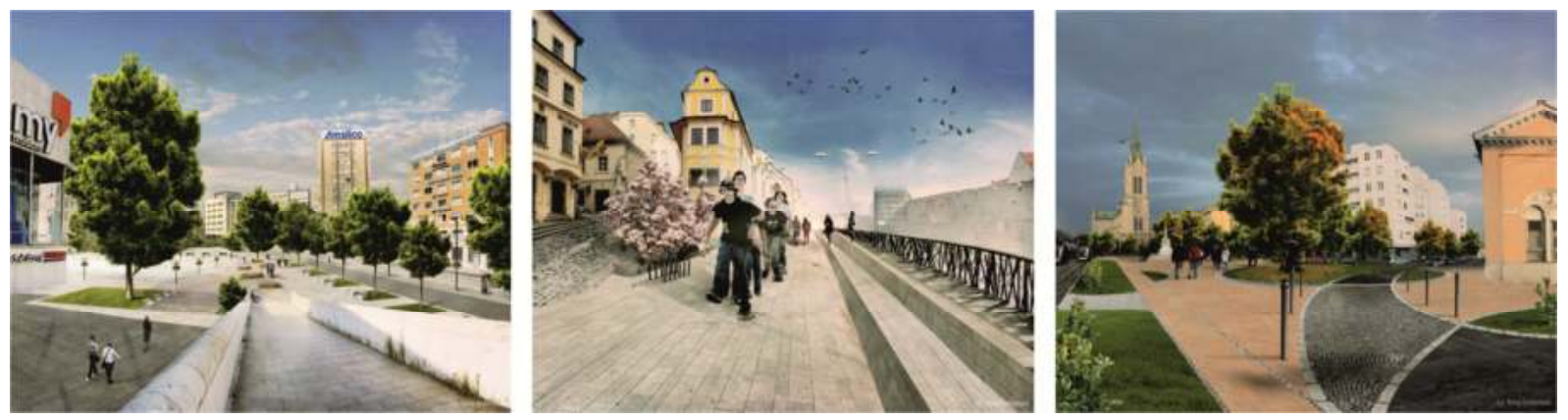

Obr.4: Ako by Bratislava mohla vyzerat’? Návrhy na lepšiu Bratislavu pre chodcov a cyklistov prostredníctvom drobných zásahov vo verejných priestoroch. Autor vizualizácií: Tony Antoniaci, člen Cyklokoalície.

\section{ZÁVERY}

Je úspešnost' verejných priestorov meratel'ná? Čiastočne áno. Ale v podstate veci nejde o meratel'nost', ide skôr o fungujúce princípy. Ide aj o posun v stratégií prístupu k premenám ulíc, námestí, nábreží a parkov.

Úspešnost' a vitalita mesta súvisia s dôrazom na verejné priestory. Nielen z hl'adiska mestskej správy a tvorby územných plánov, ale hlavne v spektre spolurozhodovania a spoločnej línie dotvárania mesta s jeho priamymi účastníkmi - obyvatel'mi, aktivistami, inštitúciami a tvorcami dizajnu mesta. Experti na kvalitu a stabilitu mestských štruktúr hl’adajú parametre zlepšovania života v dôraze na vitálne mestské priestory. Súčasné mestá nemôžu stavat' svoj imidž len na extravagantnej architektonickej 
prezentácii. Urbánne deficity života v meste signalizujú nevyhnutnost' stratégie tvorby kvalitných mestských priestorov v participácií všetkých účastníkov, s dôrazom návštevníkov a tiež na domácich obyvatel’ov. Tento princíp dáva humánny rozmer logike územného fungovania. Podmienky eko prežitia sa viažu v mestách čím d’alej tým viac na mieru a mierku človeka ako jednotlivca a jeho možností života $\mathrm{v}$ spoločenstve mesta. Mesto, ktoré uznáva dominanciu peších, potreby rovnováhy eko - urbánnych štruktúr a víziu sociálnej kultúry za spolupatričnosti jeho obyvatel'ov, má šancu položit' dôraz na verejné priestory a zvyšovat' ich kvalitu. Variantnost' urbánnej ponuky pre rôzne zoskupenia návštevníkov na námestiach je podmienkou mestských stratégií, ktoré môžu prispiet' $\mathrm{k}$ spokojnosti a oblúbenosti daných miest. Je potrebný dôraz na využitie priestorov pre rôzne aktivity, na stretnutia rôznych vekových kategórií a na ponuku variantnej kultúry, oddychu i komercie. Takto môže prirodzene stúpat' humánna a kultúrna dimenzia urbánneho života. Póly živej mestskosti: kvalitné námestie, park, nábrežie a pešiu ulicu vytvárajú mesto viac priatel'ským, pozývajú $\mathrm{k}$ zastaveniu, stretnutiu, k využitiu funkčnej ponuky daných priestorov.

„City friendly pedestrian spaces“ dodávajú mierke človeka pôvodný význam a vracajú identitu do uzlových polôh, ale aj tam, kde už bola urbánnym rozmachom nerozvážne devastovaná. Urbánna akupunktúra, s princípom sledovania života zdola, drobné zásahy, ktoré spôsobia želaný spätný efekt $\mathrm{v}$ programe celkového prosperovania mestských priestorov môžu posunút' existujúce verejné priestory na priatel'ské pre peších, čo je aktuálna šanca premien nielen pre Bratislavu.

\section{Použitá literatura}

[1] Bašová, S. Urbánna vitalita. In: Alfa 2/2014. Bratislava: Fa STU, 2014. s.19.

[2] Bencová, J. Hore, dole, vpravo, vl’avo. In: Downtown, principy a prednosti vnútromestskej štruktúry. Bratislava: Fa STU, 2006.

[3] Czafík, M. - Vráblová, E. Tvorba diferencovaného obytného prostredia $\mathrm{v}$ panelových bytových domoch a sídliskách ako nástroj zvýšenia sociálnych väzieb obyvatel’ov. In: Komplexná obnova bytových domov 2014. Bratislava: STU, 2014. 183 s. s.95.

[4] Gehl, J. - Gemzoe, L. Nové městské prostory. 1.vyd. Šlapanice: Vydavatelství ERA, 2002. 264s.

[5] Jenks, M. - Burton, E. - Williams, K.: Compact Cities and Sustainability. London: Spon Press, 1997.

[6] Kuxo, M. Ako by Bratislava mohla vyzerat? Pozri si krásne vizualizácie od cyklokoalície. [online] 23.9.2011. Dostupné na: [http://shiz.sk/articles/view/634].

[7] Porada, B. 2012 Worldwide City Rankings Reveal Important Regional Trends. [online] In: ArchDaily.7.4.2013. Dostupné na: [http://www.archdaily.com/356449/2012-worldwide-cityrankings-reveal-important-regional-trends/].

[8] Rodríguez, Y. M. L.: Princípy urbanistickej rekonštrukcie v aglomerovaných sídlach vel'kých miest: dizertačná práca. Bratislava: Fa STU, 2000.193s.

[9] Štefancová, L. Valorizácia mestotvorných štruktúr: dizertačná práca. Bratislava: Fa STU, 2014. 143s. s. 118. 